\title{
Last Year at Mulholland Drive: Ambiguous Framings and Framing Ambiguities
}

\author{
Steven Willemsen and Miklós Kiss \\ University of Groningen (The Netherlands) \\ E-mails: s.p.m.willemsen@rug.nl; m.kiss@rug.nl
}

"Sense is not the point: the responses are the point."

Stanley Kauffmann $(2001,28)$

\begin{abstract}
This article proposes a cognitive-narratological perspective on David Lynch's Mulholland Drive (2001) and the numerous contrasting interpretations that this film has generated. Rather than offering an(other) interpretation of the film, we aim to investigate some of the reasons why Lynch's highly complex narrative has gained a cult - if not classic - status in recent film history. To explain the striking variety of (often conflicting) interpretations and responses that the film has evoked, we analyse its complex narrative in terms of its cognitive effects. Our hypothesis is that part of Mulholland Drive's attractiveness arises from a cognitive oscillation that the film allows between profoundly differing, but potentially equally valid interpretive framings of its enigmatic story: as a perplexing but enticing puzzle, sustained by (post-)classical cues in its narration, and as an artcinematic experience that builds on elements from experimental, surrealist, or other film- and art-historical traditions. The urge to narrativize Mulholland Drive, we argue, is driven by a distinct cognitive hesitation between these conflicting arrays of meaning making. As such, the film has been trailblazing with regards to contemporary cinema, setting stage for the current trend of what critics and scholars have called complex cinema or puzzle films.
\end{abstract}

Keywords: narrative complexity, framing, puzzle film, art-cinema, David Lynch, Mulholland Drive.

The continuing cultural impact of David Lynch's enigmatic neo-noir thriller Mulholland Drive (2001) is striking in several respects. On the one hand, as critic Ignatiy Vishnevetsky has noted, Mulholland Drive is "an avant-garde film by most metrics," occupied with "warping filmic narrative to the edge of incoherence" (2015). Indeed, upon its release, Lynch's film was criticized by many viewers and critics for being incomprehensible or chaotic (see Andrews 2004, 25). At the 
same time, however, Mulholland Drive also gathered acclaim from a large share of moviegoers and critics: it earned director Lynch an Oscar-nomination, launched the career of lead actress Naomi Watts, gained a cult following, sparked countless analyses and readings, and ultimately became a key film that "defined the modern puzzle-box movie" (Vishnevetsky 2015). Today, almost two decades after its debut, discussions around Mulholland Drive have far from subsided. They even seemed to return to full swing following the film's 2015 re-release in the esteemed Criterion classic films DVD series, and its number one spot in BBC's 2016 massive poll of 177 film professionals, electing it as the best film of the 21st century so far. ${ }^{1}$

The main reasons for Mulholland Drive's success, besides the idiosyncratic affective qualities of Lynch's trademark style, tone, and tropes, ${ }^{2}$ have arguably been the film's narrative complexity and hermetic themes. Skillful analyses, clever explanations and creative interpretations of its plot, riddles, and possible meanings have been offered by the dozens, across both popular and scholarly platforms, and discussions on the film's thematic and narrative (in)coherence continue to attract fans, critics, and scholars alike. ${ }^{3}$

This article does not seek to provide another hermeneutic inquiry about Mulholland Drive's potential meanings, or all the thinkable thematic or allegorical reasons behind its fragmented organization; rather, what interests us is the question how the film's particular narrative complexity has attracted, fascinated and divided such a relatively large audience in the first place, and how it, to this day, keeps on spawning so many different and frequently contradictory interpretations. Mulholland Drive's complex narrative forms a remarkable case, not only because of the sheer amount, but particularly also the diversity of the responses it triggers. We hypothesize that one of the key reasons behind the film's persistent attractiveness lies in a balance that it maintains between at least two different clearly distinct options that viewers have in making meaning of its enigmatic story. These, we propose, can be understood as emerging from two different, incompatible, but equally reasonable framings allowed by the film's narrative strategies.

1 See http://www.bbc.com/culture/story/20160819-the-21st-centurys-100-greatest-films. Last accessed 26. 02. 2019.

2 For a quick glance on such Lynchian tropes - "A road at night. A woman's crimson lips. Red drapes and a spotlit stage. [...] a flicker of a lightbulb or a swelling rumble on the soundtrack, [...] an untimely pause or a charge of déjà vu” (Lim 2015, 6) - see Kevin B. Lee’s (2015) video essay, based on Dennis Lim's comprehensive book about Lynch's cinema, What Is "Lynchian"? https://vimeo.com/196761519. Last accessed 26. 02. 2019.

$3 \quad$ See, among others, Lewis 2002; Nochimson 2002; Buckland 2003; Andrews 2004; Hudson 2004; McGowan 2004, 2007; Olson 2008; Bartyzel 2010; Nieland 2012; Akser 2012; Mittell 2013; Campora 2014; Lim 2015; Winter 2015; or Bailey 2015. On IMDb, to date (26. 02. 2019), there are 1844 user and 293 external reviews of the film. 


\section{The Narrative Complexity of Mulholland Drive}

Effects of complexity - that is, a sense of temporary or permanent cognitive confusion regarding comprehension and meaning making - can be achieved through various formal-structural manipulations across most key parameters of film narration (see also Kiss and Willemsen 2017). Looking at the popular complex films that emerged from the mid-1990s onwards, one can observe experimentations in time (e.g., non-chronological arrangements of events, reversed or inversed telling, multiple timelines, spatiotemporal fragmentation), in narration (e.g., notable information gaps or overloads, incongruities, ambiguities), in focalization (e.g., unreliability, internal focalization, hidden focalization shifts and unmarked subjective realism), in character continuity (e.g., split personalities, duplications, Doppelgängers) or in complex spaces and storyworlds (e.g., multiple, multi-dimensional or parallel universes, impossible storyworlds, ontological metalepses). Of course, many of these storytelling strategies are not new to feature films, let alone to the literary narrative tradition. ${ }^{4}$ The complex and disruptive narrative forms that found their way to the mainstream film from the mid-1990s onwards were already pioneered and explored in earlier traditions of filmmaking, most notably in 1930s avantgarde films, the European modernist art cinema of the late 1950s, 1960s and 1970s (see Bordwell 1979; Kovács 2007, 120-140), and, somewhat less radically, even in the 1940s Hollywood film noir (Bordwell 2017).

Mulholland Drive draws from all these previous traditions, both in narrative and stylistic terms. However, especially for a project emerging from a commercial context, ${ }^{5}$ Lynch's film is radical in its undermining of narrative stability, mostly because it overthrows many of the above listed parameters at the same time. The film starts out as a seemingly traditional crime story in which a woman (Laura Harring) survives a car accident, suffers from amnesia, and flees into the home of a young would-be actress Betty (Naomi Watts). No longer able to remember her real name, she introduces herself to Betty as Rita. When in Rita's bag the two find a large amount of cash and a mysterious blue key, they commit themselves to investigating Rita's real background and identity. However, Betty and Rita’s

$4 \quad$ Although there is an extensive history of complex narrative experimentation in literary traditions such as modernism, the nouveau roman or the postmodern novel, narrative complexity in literature does not seem to have reached the widespread, mainstream appeal that complex films currently have.

5 Mulholland Drive was originally commissioned by the ABC channel, subsidiary of Disney, as a pilot of a potential television series. About the protracted and haunted production history of the film, see Buckland 2003 and Mittell 2013, respectively. 
journey soon disintegrates into a series of perplexing and uncanny scenes (including a Hollywood director in a casting procedure impeded by mobsters, an underworld cowboy, a story of an unhandy hitman, a nightmare manifesting in an eerie creature behind a Winkie's diner, and more), some related to, while some seemingly loose from the initial plot. The organization and hierarchy of the primary and side-events appears non-causal and a-chronological, often lacking clear spatial or temporal markers. In addition, through metaleptic destabilizations, the focalization of the primary story becomes fuzzy and intensely ambiguous, leaving spectators to wonder how and whether events are connected - in terms of spatial, temporal, causal and/or thematic relations - at all. The plot further disintegrates during the final twenty minutes of the film, when earlier introduced characters re-appear in different incarnations, under different names and roles (Betty now seems to be Diane, a has-been actress, also played by Naomi Watts), fundamentally riddling the story with contradictions and incoherencies.

Especially for first time viewers, it may appear as if Mulholland Drive features subjective unreliability, multiple ontological levels, contradictory and paradoxical elements, a non-linear progression, plus an overstimulating amount of information and incomplete plotlines, all at once. Notwithstanding this excessive complexity (which was experienced particularly strongly at the time of its release), the film apparently also kept many viewers' narrative interest alive concerning questions as to how the zigzagging events and unresolved plotlines are related, how stable character identities can be inferred from a story that constantly changes their identities, and whether episodes are embedded in each other as dreams, realities, fantasies, parallel universes, allegories, or perhaps are just meant as a set of powerful standalone scenes and playful self-reflections on Hollywood filmmaking.

\section{Responses to Mulholland Drive's Complexity}

Mulholland Drive has spawned (and keeps spawning) a remarkable amount of speculation and interpretations. From its release onwards, critics, as well as the general audience have been divided over the film, even questioning whether a (relatively) stable and coherent interpretation of it is possible at all. Sampling the available responses from critics, roughly two types of dealing with the film's complex narration emerge: treating it as either (1) a perpetually elusive mystery with no (need for a) logical way out, or (2) as an exceedingly challenging puzzle that the viewer must solve. 
(1) On the one hand, many commentators see Lynch's film as fundamentally incoherent and therefore intentionally anti-narrative. For instance, according to film critic Roger Ebert, “Mulholland Drive isn’t like Memento, where if you watch closely enough you can hope to explain the mystery. There is no explanation. There may not even be a mystery" (2001). Likewise, writer and editor Jennifer A. Hudson argues that the film "remains a spiral, a circle, a series of unexplained pulsions that blur and destabilize traditional concepts of intellectual sense. [...] Once Mulholland Drive becomes your universe, you will find yourself lost in confusion" $(2004,17,23)$. Whereas some reviewers found this to be a reason for dismissing the film - accusing it of being a "chaotic" "dead-end journey," a "headscratcher without continuity" (for an overview see Andrews 2004, 25) -, the perceived lack of narrative coherence was hailed by other interpreters as the film's primary achievement. For example, New York Times critic A.O. Scott argued that while Mulholland Drive's "tangled story will be experienced by some as an offense against narrative order, [...] the film is an intoxicating liberation from sense" (Scott 2001). Many interpreters who have taken this position imply that Mulholland Drive's fragmented anti-narrative makeup primarily serves not story-relevant, but more aesthetic, thematic, expressive, or even meta-fictional aims. Such interpretations assume, as Justus Nieland argued, that Mulholland Drive is "exploiting the ambiguities of art cinema, setting into motion its most obviously self-referential categories (time, cinema, spectatorship, authorship)" (2012, 97). Reflecting on the amount of symbolic and symptomatic readings of Mulholland Drive, Jason Mittell has highlighted how many of its reviewers have felt that the resolution of the film requires "beneath the surface" interpretation, "where we can find readings of the film as illustrating Lacan's theories of fantasy, desire, and reality; evoking contemporary technologies of virtual reality; dissolving boundaries between semiotic oppositions; offering a lesbian tragedy as an indictment of homophobia; and critiquing the dream-crushing logic of Hollywood cinema, among many others" $(2013,28)$.

(2) On the other hand, however, another, equally substantial group of viewers does not see Mulholland Drive as fundamentally or intentionally incoherent at all. Rather, they read it as a puzzle that just needs some rearranging and deciphering for the story to make logical sense. In Matthew Campora's words, "a growing consensus of commentators" argues that "although Mulholland Drive has affinities with the open-ended narratives of art cinema, its fragmented multiform plot structure does allow for a coherent narrative reading" $(2014,69)$. Building on the categorization of critical work by David Andrews (2004, 25), Campora divides the 
interpretations of this set of reviewers up into two camps: critics who have argued that the film is a fully coherent "utterly comprehensible" narrative of subjective realism, and those who find that the film is complex, but "mostly comprehensible with varying degrees of incoherence" $(2014,74)$. Jason Mittell has noted how this share of viewers and critics tends to behave like "forensic fans" (2009). For them, making sense of the film is mostly "a question of comprehension, trying to make coherent sense of the film's narrative events" (Mittell 2013, 27). ${ }^{6}$ Regardless of the accuracy or (scholarly) value of the different interpretations, this forensic engagement is paramount to the pleasure the film offers to many of its viewers. The evidence for this unappeasable puzzle-solving appeal can be found not only in academic journals and books, but especially also on many blog posts, websites, and online discussion boards. As Lynch biographer Dennis Lim notes, "audiences who responded to Mulholland Drive loved it precisely for its unique architecture as a puzzle movie that required some degree of assembly in the viewer's head" $(2015,154)$. This pleasure taken in piecing together the film's story differs from the earlier identified - more symbolic, thematic or subtextual - responses in that it is occupied with story logic, re-ordering of scenes and occurrences into a more or less stable, chronological, causal, and diegetically motivated chain of events.

So how can these contrasting interpretive stances co-exist? We see these divergent responses as two fundamentally different ways of dealing with the narrative's complexity: one works to preserve incongruities by attributing a variety of artistic strategies or meanings to the incoherence, while the other is mainly occupied with resolving and naturalizing the complexity and ambiguity into a coherent story. We propose to understand these two meaning making pulls as two different ways of framing the film's narrative complexity, both of which are evoked and afforded by Lynch's film through textual and contextual cues.

\section{Frame Theory and Mulholland Drive}

Frame theory provides a particularly useful conceptual tool to get a grip on viewers' interpretive operations. In its most common use, frames refer to dynamically applied structures of memorized knowledge that become active in response to familiar situations and settings. In the words of its pioneering theorist Marvin Minsky, a frame is "a data-structure for representing a stereotyped situation, like

6 "The most common explanation for the film's narrative is that the first $80 \%$ of Mulholland Drive is Diane Selwyn's (Naomi Watts) dream imagining herself as Betty Elms while the final act portrays the reality she is trying to escape” (Mittell 2013,27). 
being in a certain kind of living room, or going to a child's birthday party. Attached to each frame are several kinds of information. Some of this information is about how to use the frame. Some is about what one can expect to happen next. Some is about what to do if these expectations are not confirmed" $(1974,1)$. Frame theory offers a heuristic tool to conceptualize mental structures of knowledge that function top-down (in response to available bottom-up cues) to control the cognitive effects of a given situation. Frames can be seen as cognitive shortcuts that help to set expectations, steer attention, recognize patterns, detect novelties, determine salience, evaluate available information and choose further actions. Framing then refers to the activity of selecting the clusters of knowledge and interpretive stances deemed the most appropriate in response to the given situation.

Cognitive narratologists have widely adopted the notion of frames (or scripts or schemata) ${ }^{7}$ to conceptualize how narrative understanding takes shape by recourse to memorized knowledge and patterns from previous real life and mediated experiences (for example, see Bordwell 1985; Branigan 1992; Jahn 1997; Herman 1997; or Caracciolo 2012). In the case of film viewing, frame theory offers a tool to describe how viewers rely on previous experiences, knowledge, and strategies in their encounter with new cinematic narratives. This can be particularly important regarding complex narratives, the challenges of which often test and play on viewers' reliance on their knowledge clusters. Some cases of complex, non-conventional, or anti-mimetic narratives may even foreground or even problematize these basic processes, emphasizing the central role of framing decisions (such as to what genre, style, or artistic tradition we take a work to belong to) in interpretation and evaluation. As Liesbeth Korthals Altes has noted, "as soon as contexts are less clear in their framing indications, readers need to select between alternatives according to the relevance context they construct for the case at hand" $(2014,33)$. Moreover, as she continues, "some kinds of texts, and some kinds of reading strategies, require that we hold in mind alternative, conflicting framings and oscillate between them, as this may result in pleasurable ('aesthetic') mental activity" (2014, 33).

As indicated, we consider one of the main reasons behind Mulholland Drive's persistent attractiveness to be a balance that the film maintains between at least two different pulls on viewers' meaning making, as evident from the contrasting responses by critics and viewers. This, we propose, can be understood as emerging from two different but equally reasonable framing options of the film's

$7 \quad$ "Whereas scripts typically represent sequences of events, frames and schemata represent points in time" (Alber 2009, 94). 
complexities between which viewers' meaning making can oscillate. As we will elaborate below, the two opposing poles of these pulling forces are

- on the one hand, a classical narrative drive, nourished by immersive story patterns and familiar generic and narrative conventions; ${ }^{8}$

- as well as this narrative drive's post-classical puzzle variant, asking from viewers to reorganize linearity, chronology, or untangle embedded levels, thereby luring them to keep trying to restore narrative order from the complex narration; and,

- on the other hand, the option of an art-cinematic appreciation, which offers an alternative to the problematized classical narrative recuperations of story logic, and which is fed by the recognition of elements from experimental, surrealist, or other film- and art-historical traditions.

The mutability between these simultaneously enticing positions, we assume, leaves the interpretative process in a permanent instability that is paramount to the film's complexity, as well as its sustained attraction. To understand the different framings of Mulholland Drive, the analysis should focus on both formaltextual characteristics of the film's narration as well as its relevant contextual components (genre tradition, production and reception histories, etc.). ${ }^{9}$ The next two sections aim to provide a detailed explanation about the ingredients that make up the opposing but co-existing forces through which the art-cinematic and (post-)classical poles allow simultaneously applicable interpretive framings.

8 Classical narration is the dominant paradigm of film storytelling, and also the mode of film viewing that most western spectators are mainly accustomed to (see Bordwell 1985, 156-204). Traditionally, classical narrative films have been constructed in ways that allow viewers to integrate the presented events into a chronological event-chain that provides a clear cause and effect logic, and that leads to some kind of closure with regards to main goals and questions posed in the story. Classical narration also usually implies that the story adheres to the laws of the everyday world in terms of spatiotemporal, logical, and physical laws (unless indicated otherwise, either by explication or through established genre conventions) and implies a sense of realism in that spectators have epistemological access to the story's ontologically knowable world.

9 After all, viewers do not just respond to textual cues - such as style or narration - when making sense of a complex narrative, but also work with contextual, paratextual and intertextual inferences - such as knowledge about a film's context of production, its relation to other films, genres and film-historical traditions, or earlier meaning-making that they found successful with comparable films - in order to choose pertinent interpretive pathways. We propose that the experience of narrative complexity emerges from this contextually situated, dynamic interaction between spectators and a work of narrative art (see also Kiss and Willemsen 2017). 


\section{Framing Complexities: Art-Cinematic Readings}

The first set of responses that we identified links Mulholland Drive to the tradition of art cinema - or, more specifically, has used interpretive and evaluative routines from the art cinema tradition to get a grip on the film's excessive narrative complexity. Art cinema has been recognized as constituting a narrative mode (Bordwell 1979; Kovács 2007) and/or institutional context (Neale 1981; Thanouli 2009; Andrews 2010) of filmmaking, characterized by its own formal, stylistic, interpretive, contextual, and economic norms that are often defined in opposition to the classical narrative film.

To substantiate such readings of Mulholland Drive, critics and scholars often point to textual cues connecting Lynch's film to notable art films and traditions, such as the surrealist cinema of the likes of Luis Buñuel (beyond Nieland 2012, 111, see for instance also Eig 2003, or Panek 2006, 66), German Expressionist cinema (Campora 2014, 70-73), or the associative, dream-like trance films such as Maya Deren's 1943 Meshes of The Afternoon (Perlmutter 2005). The most frequent comparison is that to the cinematic modernism of the late 1950s, 1960s and 1970s found in the films of prominent auteurs such as Federico Fellini, Ingmar Bergman, or Alain Resnais and Alain Robbe-Grillet. ${ }^{10}$ For András Bálint Kovács, contemporary complex films like Mulholland Drive are "systematic manifestations of several sophisticated modernist narrative procedures 'infiltrating' probably the world of quality Hollywood production" $(2007,60) .{ }^{11}$

Many of the film's narrative strategies and thematic choices indeed seem inherited from the art-cinematic tradition: the dissolution of boundaries between reality and dreams, hallucinations, fantasies, or subconscious projections (or

10 Modernist art films have pioneered many forms of complex storytelling in film narration, foregrounding ambiguities, contradictions, permanent gaps, spatiotemporal fragmentation, distorted and highly subjective narration (often including dreams, memories or fantasies), thematic or even political emphases, loosened causality, and other relatively radical modernist techniques (for encompassing overviews, see Bordwell 1979 and Kovács 2007, 57-62).

11 Other scholars too have drawn such connections between techniques explored in earlier - mostly modernist - art films and narrative experimentations trending in contemporary complex films (e.g., Cameron 2008; Klecker 2011; Campora 2014; Kiss and Willemsen 2017). To illustrate the habituation effect of complex storytelling techniques, Cornelia Klecker recalls the analogous movement in literary history by which "modernist novels, such as works by Virginia Woolf and James Joyce, were exceedingly avant-garde at the time they were published, yet they became established classics in the second half of the twentieth century" (Klecker 2011, 24). According to András Bálint Kovács, "the fact that Mulholland Drive was not only made but that director David Lynch was awarded an Oscar nomination for it proves that narrative ambiguity, which was introduced into modern cinema by Alain Resnais and Alain Robbe-Grillet as a highly avant-garde artistic element, forty years later has finally become a mainstream norm” (Kovács 2007, 60). 
however else one might rationalize some of the film's perplexing story paths), as well as its deconstruction of realist spatio-temporality and character-integrity are easily associated to the surrealist films of the pre-1930s European avant-garde (Ebert calls Mulholland Drive "the first surrealist film of the 21st century" [2002]), as well as to the post-war European modernist tradition (Ingmar Bergman's 1966 Persona is probably the most often-cited title of reference). Besides its manifest conflation of objective (zero focalized) and subjective (internally focalized) modes of narration, other strategies of storytelling that are particularly reminiscent of the post-war European modernist tradition are the film's utilization of metafictional and self-reflexive elements (thematizing the struggles of its own creation, Lynch's film often invites a comparison to Federico Fellini's 1963 81/2 [Otto e mezzo]), the story's foregrounding of ambiguities and incongruent versions of events (Alain Resnais's 1961 Last Year at Marienbad [L'année dernière à Marienbad] is another recurring association, being one of the few films that can concur with Mulholland Drive in terms of the amount and variety of interpretations that it has spawned), and the deconstruction of elementary - and therefore rarely challenged - parameters of classical narration (for instance the bizarre shifting, splitting or collapsing of characters - which is not uncommon in art cinema, such as in Bernardo Bertolucci's 1968 Partner or, indeed, Bergman's Persona).

These associations with art cinema are further reinforced by Lynch's trademark style: his idiosyncratic offbeat cinematography - hand-held obscure point of view shots, superimpositions, shaky focus, etc. -, lighting - more atmospheric than communicative -, acting and characterization - remember Betty's inconsistently extreme acting skills "from guileless pretending to majestic double-dealing" (Toles 2004, 8) -, and choice of soundtrack - eerie soundscapes and dreamy but ominous music from Angelo Badalamenti's "darkest yet" main theme (Norelli 2009, 41) to Rebekah del Rio’s a cappella version of Roy Orbison's Crying -, all together convey a hypnotic and expressionistic quality.

Prototypically, as Torben Grodal writes, "art film combines stylistic innovation with a claim to higher meaning" on the narrative level (2009, 207-8). For many viewers, Mulholland Drive ticks both boxes. Cued by these narrative, thematic, and stylistic elements, and possibly further guided by contextual knowledge (e.g., knowledge of Lynch's earlier work and his reputation as an 'auteur director; the film's success at the Cannes Film Festival; or its presence in the context of arthouse institutions or academic journals), viewers may find sufficient reason to conclude that the ambiguities of Mulholland Drive should be understood and interpreted in light of the art-cinema tradition. 
Framing a film as art film comprises a reasoned appraisal relating to a significant set of cognitive, interpretive and evaluative routines, distributed to viewers through art cinema's narration, institutions, and practices. Especially when confronted with the excessive complexity of "non-naturally coded texts" (Fludernik 1996, 36), experienced art-cinema-literate viewers can make use of a variety of symbolic or even symptomatic meaning-making strategies that are alternative to their more referential and explicit narrativizing routines trained in classical narratives. In other words, when a story's complexity or confusing effects become extensive or foregrounded, and leave little chance for a classical narrative recuperation, the art-cinema frame of viewing can offer alternative interpretive paths, promoting the construction of meaning beyond the more strict mimetic and referential narrative sense. Art films have traditionally cued, invited, and perhaps even trained viewers to downplay the importance of plot, concrete events, and explicit meanings. Invoking a broader pallet of possible mimetic recuperation, they promote poetic, lyrical, associative, contemplative allegorical, style-driven or expressionistic modes of meaning making (see also Bordwell 1979; Grodal 2009, 207-209; Kiss and Willemsen 2017, 156-163). One may for instance infer that a narrative's incoherence forms the film's deliberate point, as, for example, signalling the fallibility of memory, illustrating the instability of perception, or representing a fundamentally ambiguous condition humaine.

As we noted, many such readings have been inferred by viewers of Mulholland Drive. Interpreters have seen the film as, among others, a deliberate "reversal of coherence" demonstrating the point where "language fails to define and construct reality" (Hudson 2004, 23), an illustration of "the role of fantasy in providing reality with structure" in a Lacanian fashion (McGowan 2004, 68), or as an "embodiment of postmodern theory" such as the hyperreality of simulacra, the pastiche as blank, meaningless parody, or the Lacanian construction of self (Bartyzel 2010). Apprehension under the art-cinematic frame is also more prone to recognize explicitly 'meta-fictional' forms, directing attention at the very process of narrative understanding and its raw materials, or at the artistic or medial tradition in which a work self-consciously stands. In his book on Lynch, Justus Nieland epitomizes this meta-fictional aspect of art-cinematic readings, claiming that "the historical horizon of art cinema is of particular relevance [for Mulholland Drive] because of the familiar challenges its modernist textuality poses to the kinds of personalities associated with Hollywood cinema - their psychologies, their affects and motivations, their relationships to the structuring of space and time, their status as erotic spectacles, their 'aura,' and their reification in stardom” $(2012,96)$. 


\section{Framing Complexities 2: (Post-)Classical Narrative Readings}

Notwithstanding these art-cinematic interpretations of Mulholland Drive, an equally substantial share of viewers does not downplay the possible coherence of the film's events and their referential meaning at all. Rather, these forensic viewers see the film as a puzzle to be solved, and pursue explanations and interpretations that provide narrative logic and closure to its challenging story and structure. We would not suggest that these attempts are misguided, or that such viewing strategies are not being film-literate enough to possess and employ the necessary modernist or artcinematic meaning-making competences (although familiarity with art-cinematic conventions and routines can certainly play an important role). Rather, we would argue that next to its invitation of applying art-cinematic framings to its ambiguities, Lynch's film simultaneously warrants an explicit and referential meaning-making of a more classical narrative stance, appealing to coherent narrativization, real-life cognitive parameters and other conventional mimetic patterns.

It must be noted that Mulholland Drive appeared at a moment when more art-cinematic viewing strategies had begun being applicable to more mainstream fiction films. In Dennis Lim's words, “Mulholland Drive coincided with a mounting appetite for narrative complexity. Audiences were by then accustomed to the shifting time signatures of Quentin Tarantino's movies, or to the gentler fissures in the films of the Polish director Krzysztof Kieślowski, who explored the cosmic patterns of interlocking lives in The Double Life of Véronique (1991) and the Three Colours trilogy (1993-1994). The rug-pulling trickery of hits like The Usual Suspects (Bryan Singer, 1995) and The Sixth Sense (M. Night Shyamalan, 1999) popularized the notion of narrative as a game; Christopher Nolan's reverse-chronology Memento (2000), another amnesia neo-noir, was released several months before Mulholland Drive, and temporal loops were becoming an increasingly common device, in such films as Donnie Darko (Richard Kelly, 2001; Primer (Shane Carruth, 2004) and Déjà Vu (Tony Scott, 2006)” (2015, 155).

Most of these contemporary complex films, however, retain fairly classical narration in that they counter their complexities with a strong reliance on classical storytelling patterns, ensuring their viewers' narrative interest, sense-making drive, and, ultimately, comprehension. Although Mulholland Drive arguably appeared as part of this emerging line of "mainstream complexity" (Kiss 2012), it cannot be unproblematically grouped with these (post-)classical narratives. Lynch's film strays away from many principles of classical narration maintained by puzzle 
films like The Sixth Sense or The Usual Suspects; but simultaneously, unlike most modernist art films, it also preserves some powerful features of classical narrativity. These appeal to viewers' habitual narrativizing urge, luring them into attempts to construct a more-or-less objective, causal, and chronological story.

In the final section of this article, we call up and review five (post-)classical storytelling strategies common to many contemporary complex popular films, which also seem to actuate interpretive cueing functions in Mulholland Drive. These classical narrative cues include the presentation of stories with [1] a high degree of tellability, [2] local and global narrative cohesion devices, [3] palpable genre conventions, [4] the opportunity for character identification as well as [5] recourse to naturalization and rationalization.

[1] The notion of tellability is used in narrative theory to refer to the quality that makes a story worth telling (or engaging to listen to). Although this quality is highly subjective and context dependent, some elementary features make certain stories more tellable than others. Jerome Bruner observed a key feature of "canonicity and breach," meaning that "to be worth telling, a tale must be about how an implicit canonical script has been breached, violated or deviated from" $(1991,11)$. That is, for a story to be worth telling, something out of the ordinary should happen in it. Such script breaches, however, can themselves be highly conventionalized, as the driving forces behind most classical and canonical narratives are (e.g., murder mysteries, romantic encounters, quests, impending threats to peace, and so on).

In terms of establishing a tellable story, Mulholland Drive's exposition could have been that of a highly classical mystery plot. In the opening half hour, the narration rather rapidly establishes an initial setting, incites the action through unexpected events, poses further questions, and paves the way for additional complications - all conforming to the classical crime narrative tradition. Viewers are being introduced, in a swift action-reaction pattern, to a woman who is threatened by a gun but then involved in a mysterious car crash, suffers memory loss, and flees into the house of Betty, a young aspiring actress. Together, they start a quest to uncover the true identity of the amnesiac woman, who carries a large sum of cash and a mysterious blue key. Most certainly, these central questions and enigmas hook many viewers just by playing on the element of curiosity. After all, as Raphaël Baroni reminds us, "it is assumed that there is a general human interest for stories reporting events that have a certain degree of unpredictability or mystery" (Baroni 2011). In short, before Mulholland Drive's narrative submerges in its more experimental and potentially incoherent paths (around the two-third 
mark), the film first sets in motion an eventful and suspenseful plot with high tellability, posing well-defined mysteries and narrative questions. These work to bias viewers to actuate an explicit and referential classical narrative reading based on potentially familiar narrative parameters.

[2] Similar story-centric inclinations are stimulated by the film's fairly conventional use of narrative and stylistic techniques on the local micro-level (i.e., within and among directly connected scenes). Again, especially in the opening parts - which set viewers' first hypotheses, and are therefore crucial in determining the framing through which one approaches the film - Mulholland Drive features many familiar formal-structural elements known from classical plotting. David Bordwell's term, cohesion devices, brings a common denominator to such narrative strategies, identifying them as "formal tactics that link passages at the local level - from scene to scene or from one group of scenes to another [...] usually serving to tighten up linear cause and effect" (2002, 95 - our emphasis).

Many of the scenes of Mulholland Drive adhere to rules and norms of classical filmic representation - principles based on providing smooth continuity in information distribution. Simply put, by its apparently undisturbed chain of action-reaction, the film looks and feels like a classical Hollywood movie following the laws of classical narrative filmmaking. As Todd McGowan observes, "the mise-en-scène conforms on the whole to the conventions of the typical Hollywood film: scenes are well lit, conversations between characters flow without awkwardness, and even the plainest décor seems to sparkle" (2004, 68). Also "the editing also tends to follow classical Hollywood style, sustaining the spectator's sense of spatial and temporal orientation" $(2004,68)$.

Yet although events initially seem connected in an ordinary, logical manner, are organized "according to a familiar temporal logic," and "occur in chronological order and follow the laws of causality" (73), their combination on the global macro-level does not provide a clear, coherent and cohesive story. ${ }^{12}$ In this sense, Mulholland Drive fits the definition of Umberto Eco's "impossible possible world" (1990, 77): it presents a storyworld that is seemingly coherent and in compliance with the logic of real-world laws, but which also introduces narrative elements or even an overall narrative structure - that will strike viewers as incongruent or impossible (with regard to both the internal laws of the storyworld and our sense of real-world logic).

12 A less ambiguous but quite clear and bold signalling of global incongruity happens in Lynch's Lost Highway, where protagonist Fred Madison (Bill Pullman), at two different and locally unproblematic moments in the plot, buzzes himself at the door of his home to report: "Dick Laurent is dead." 
[3] Another key contributor to the film's classical narrative appeal is Lynch's evocation of popular cinematic genre conventions - in plot, but also through prototypical characters, settings, tropes, patterns, cinematography and style. Genre conventions commonly guide viewers in their apprehension, comprehension, and evaluation of films, as these conventions come with strong expectations and interpretive routines, predominantly tied to the classical narrative tradition. As such, issues of genre are often central in framing decisions. ${ }^{13}$

Like in his television series Twin Peaks (with Mark Frost, 1990-1991, 2017), or feature films like Blue Velvet (1986), Lost Highway (1997) as well as Mulholland Drive, Lynch's stories frequently revolve around central mysteries that are very strongly generically coded. As Elliott Panek notes, both "Lost Highway and Mulholland Drive use the detective trope to provoke the audience into looking for answers that the film doesn't provide" $(2006,76)$. The recognition of familiar thematic (an enigmatic femme fatale, a hitman, a mysterious creature, mobsters and cowboys) and stylistic tropes (a dark and dreamy soundtrack, chiaroscuro lighting and inquiring camera movements) signals a neo-noir detective mystery, cuing viewers into framings that activate a genre-specific routine: to inspect, puzzle, and deduct along with the characters. The recognition of the classical mystery genre in Mulholland Drive fosters viewers' expectation and desire that their investigative efforts in resolving both the story's and the narration's mysteries will ultimately pay off - after all, classical narrative genre films commonly provide such closure and coherence. ${ }^{14}$

In Mulholland Drive, strong generic patterns may put viewers on a classical narrative track of resolving the film's complexities, thereby downplaying artcinematic readings that would accept or even celebrate unresolved ambiguities as an artistic, authorial strategy. ${ }^{15}$ Investigative, puzzle-oriented readings of the

13 As Daniel Chandler highlights, "key psychological functions of genre are likely to include those shared by categorization generally - such as reducing complexity [...]. Genre theorists might find much in common with schema theorists in psychology: much as a genre is a framework within which to make sense of related texts, a schema is a kind of mental template within which to make sense of related experiences in everyday life. From the point of view of schema theory, genres are textual schemata” (1997).

14 This desire can be strategically played upon. For example director Christopher Smith, in the DVD commentary (2010, Icon Film Distribution) to his exceedingly complex Triangle (2009), reveals his strategy to appeal to his viewers' interpretive routines trained in the horror genre. According to him, viewers engage with his film's complex incongruities in a rational and analytical manner "because it's a horror" - that is, "because it's a movie that is watched primarily by an audience that are very into logic, and they want it to make logical sense" (Smith 2010).

15 Monika Fludernik emphasizes the importance of genre cues with specific regards to the interpretation of difficult narratives. She argues that: "when readers are confronted with potentially unreadable narratives, texts that are radically inconsistent, they cast about for ways 
film are further reinforced by recurring narrative patterns and props such as the mysterious blue key and box. These items appear salient and significant because of their recurrence during pivotal moments of the film's narrative; yet what exactly they signal, or how they could work as narrative orientation points, is left unclear or ambiguous, making these objects some of the most discussed and speculated about elements in the film's story.

[4] Another strategy often found in contemporary complex films is the appeal to classical forms of character identification. Classical film narratives typically present accessible protagonists with whom viewers can connect and resonate relatively easily; they are psychologically transparent, meaning they have rational motivations and clear goals, display relatively unambiguous behaviour, and are emotionally and actively invested in the story's events and action. Such lifelike classical protagonists - the types about whom we easily come to care - play a key role in winning our affection, empathy or identification, thus enhancing a narrative's tellability by providing viewers' entry points into the story.

In the opening hour of Mulholland Drive, Rita, Betty, and film director Adam (Justin Theroux) all seem to provide such access points. Both Betty and Rita function like detectives, channelling the curiosity and rationalizing urge that viewers may have while trying to figure out the story's mysteries. Naomi Watts's Betty particularly appears as a highly classical, quite generic protagonist (at least during the first two thirds of the film): she is a warm-heartedly kind character with "the attractive innocence of a new arrival in Hollywood, someone eager to make her way as a performer" (McGowan 2004, 77). Throughout the film, however, these familiar and unambiguous character traits become increasingly unstable - a disintegration that strongly contributes to the feeling of overall narrative fragmentation and incoherence towards the end of the film. Nonetheless, the confusing changes, through which Betty gradually departs from the heroine role and ultimately morphs back into her alternative (or real) frustrated Diane Selwyn, come only late in the plot, right when immersed viewers may have felt just one step away from untangling the film's puzzle.

[5] Strong incongruities, like strong narrative incoherencies or inconsistencies in character integrity, ask for naturalizations - mimetic motivations that rationalize such discrepancies within the story(world). The term naturalization was coined by Jonathan Culler (1975) and later influentially appropriated by Monika Fludernik (1996) to describe interpretive strategies by which readers (or

and means of recuperating these texts as narratives - motivated by the generic markers that go with the book" $(1996,34)$. 
viewers) reconcile textual inconsistencies by fitting them into overarching sensemaking patterns. The earlier discussed art-cinematic readings of Mulholland Drive provide examples of one type of interpretations that alleviate detected incongruities: they offer naturalizing readings of the fragmented plot structure as, for instance, Lynch's deliberate reversal of coherence and destabilization of traditional logic (Hudson 2004), as an intoxicating liberation from logical sense (Scott 2001), as a Lacanian psychoanalytic study in the construction of identity and the self (Akser 2012; McGowan 2004), or as an examination of postmodern concepts such as the simulacrum (Bartyzel 2010). Viewers who take a more classical narrative frame of viewing, however, tend to opt for different naturalization strategies. Rather than through indirect intellectual or discursive interpretive efforts like those that characterize the above art-cinema readings, naturalization within classical narrative framings is usually sought in more direct referential parameters and diegetic motivations on the level of the storyworld. Most mainstream movies that feature complex storytelling provide mimetic motivations through which viewers can rationalize the film's narrative anomalies: one can think here of supernatural, (pseudo-)scientific, (quasi-)rational or (quasi-)realistic storyworld elements such as time machines, crooked quantum mechanical reasoning, or focalizing characters who suffer from mental illnesses or hallucinations. Mimetic motivations like these offer explanatory mechanisms that direct viewers' attention towards the internal laws of the storyworld, and that downplay the need for the invocation of allegorical or symbolical paths of naturalization. Amateur as well as scholarly forensic fans of Mulholland Drive have vigorously sought for mimetic storyworld motivations to explain, naturalize, and rationalize the film's confusing narrative makeup, construing it almost invariably as a projection of one of the characters' subjective reality. Although interpreting incongruous narrative events as someone's exteriorized subjectivity had long been a strategy primarily associated with art cinema (see, among others, Kawin 1978; Bordwell 1985, 206), the success of films like David Fincher's Fight Club (1999), Spike Jonze's Being John Malkovich (1999), Christopher Nolan's Memento (2000), or Ron Howard's A Beautiful Mind (2001) had made subjective realist narration (and its corresponding viewer interpretations) a mainstream trend by the time Mulholland Drive was released. As a result, many interpreters have sought to resolve and naturalize Lynch's mysteries by assigning focalizers from whose minds the narrative anomalies originate (for a comprehensive account, see Campora 2014). Attempting to discern what belongs to a dream, fantasy, or perhaps a post-mortem hallucination, and what to the reality that frames it, many 
viewers have argued for various relatively consistent explanations of the film as being largely a dream (the imaginary world of Betty) that covers up (and/or is occasionally disrupted by) a darker narrative reality (the actual life of Diane). Mulholland Drive contains many clues that cue and support this subjective realist reading, ranging from the film's stylistic tropes (reminiscent of surrealist and expressionist techniques) and the signposted ruptures between the plot's first and second movements (a clear division that also characterizes Lost Highway, yet seems badly missing from Lynch's utterly confusing 2006 Inland Empire), to the incongruently returning characters (appearing in different roles) and other, more specific narrative clues such as the cowboy's potential raisonneur role in telling Betty/Diane that it is "time to wake up" (a moment that many interpreters take to be an authorial intervention indicating a dream narrative). Notwithstanding the abundance of these clues and triggers, the exact relation between the subjective and objective frames of narration remains indeterminate, resulting in a wellbalanced ambiguity that can allow for a rich interpretive game in which narrative elements can still acquire a range of different meanings.

\section{Interpretive Multi-Stability as a Viewing Effect}

In sum, Mulholland Drive offers a powerful demonstration of how different framings and viewing stances can entail very different appraisals of the same work. The resulting effect of the film's manifold affordances and viewers' potential oscillation in-between those is reminiscent of what Tzvetan Todorov has called "the fantastic" in literature (1975). Todorov characterized the fantastic as a particular (temporary or ongoing) hesitation - a "cognitive uncertainty" as to how a story's strange elements should be understood or explained: either as part of the "uncanny" (i.e., as originating from the subjective perception or mental state of one of the characters) or of the "marvellous" (i.e., as part of a supernatural storyworld). Moreover, according to Todorov, the fantastic requires not only "a hesitation in the reader and the hero; but also a kind of reading, which we may for the moment define negatively: it must be neither 'poetic' nor 'allegorical'” (1975, 32). Remarkably, while in Mulholland Drive elements of uncanny and marvellous fiction are both in the mix, poetic or allegorical modes of reading are also afforded by the film's ambiguous narration. Expressionistic, surrealist, allegorical or authorial motivations all may become part of a continuous cognitive framing and re-framings that viewers can try out in their meaning making. It is exactly this distinct interpretive multi-stability, allowing viewers to apply and keep switching 
between a multiplicity of cognitive framings, that has arguably made Lynch's film one of the most enduringly debated pieces of 21st-century cinema.

It must be noted that in the case of Mulholland Drive, this interpretive elusiveness may for some viewers also enhance the viewing experience beyond the strictly narrative - i.e., by affording stronger engagement with the film's perceptual, bodily, affective, or associative effects. In a 1997 article reporting from the set of Lost Highway, David Foster Wallace eloquently captured this powerful aesthetic potential of Lynch's cinema. Contemplating what fascinates him about Lynch's work, Wallace noted that "David Lynch's movies are often described as occupying a kind of middle ground between art film and commercial film. But what they really occupy is a whole third different kind of territory. Most of Lynch's best films don't really have much of a point, and in lots of ways they seem to resist the film-interpretative process by which movies' (certainly avant-garde movies') central points are understood. [...] This is one of the unsettling things about a Lynch movie: You don't feel like you're entering into any of the standard unspoken and/or unconscious contracts you normally enter into with other kinds of movies. This is unsettling because in the absence of such an unconscious contract we lose some of the psychic protections we normally (and necessarily) bring to bear on a medium as powerful as film. [...] This is why his best films' effects are often so emotional and nightmarish" $(1998,170)$. Mulholland Drive's cinematic (anti-)logic can indeed feel all the more nightmarish exactly because it escapes our grasp. But this, as we have demonstrated, does not stop viewers to appraise the resulting experience.

In light of current debates in film theory, it is interesting to observe how the diverse interpretive framings of Mulholland Drive mirror, and actually expose, different stances in the theoretical conceptualization of narrative complexity in general. Film scholars have been divided in their attempts to understand, categorize, and evaluate the wave of complex narratives in contemporary film. Dispute has emerged over whether contemporary complex films should be seen as an altogether new phenomenon, with distinct strategies, conventions and viewing effects, or as still belonging to and rooted in the tradition of classical narrative cinema. On the one hand, some have proposed that today's complex films are merely "trickled down" mainstream incarnations of previous artcinematic storytelling experiments (e.g., Kovács 2007, 60; Cameron 2008; Klecker 2011), whereas other scholars have argued that the trend should mostly just be seen as a series of intensified variations - mere complications - of longestablished and prevailing classical narrative principles (see, most notably the 
consistent contentions of Bordwell and Thompson 2013). ${ }^{16}$ Also others have sought to define contemporary complex films as some form of novel hybrid, seeing them as a new and distinctly post-classical breed of puzzle films that question or deconstruct the narrative principles by which they are governed (such as linearity, causality, coherence and congruity, or the relative trustworthiness and transparency of narration) and that "suspend the common contract between the film and its viewers" (Elsaesser 2009, 19; see also Thanouli 2006; Buckland 2009, 2014; or Elsaesser 2017). Although it was not our intention to directly engage with these ongoing scholarly debates here, it became apparent that in the case of Mulholland Drive, viewers' stances actually correspond to all these different conceptualizations. Perhaps what this soft conclusion signals is a reminder that theoretical definitions of narrative complexity are themselves imbued with framing activities and interpretive stances, and that the scholarly and critical discussions of these films might concern the elusive workings of interpretation as much as they concern formal developments and shifts in film narration and narratives per se.

\section{References}

Akser, Murat. 2012. Memory, Identity and Desire: A Psychoanalytic Reading of David Lynch's Mulholland Drive. Cinej Cinema Journal vol. 2, no. 1: 59-76. https://cinej.pitt.edu/ojs/index.php/cinej/article/view/58/192. Last accessed 26. 02. 2019.

Alber, Jan. 2009. Impossible Storyworlds - and What to Do With Them. StoryWorlds: A Journal of Narrative Studies vol. 1: 79-96.

Andrews, David. 2004. An Oneiric Fugue: The Various Logics of Mulholland Drive. Journal of Film and Video vol. 56: 25-40.

Andrews, David. 2010. Art Cinema as Institution, Redux: Art Houses, Film Festivals, and Film Studies. Scope vol. 18: 1-21. https://www.nottingham.

16 David Bordwell finds that the "debate about postclassical Hollywood raises the question of how to gauge change over history. On the whole, I think, critics have exaggerated the novelty of current developments. This isn't surprising, since our perceptual and cognitive systems are geared to take a great deal for granted and to monitor the world for change. We are sensitive to the slightest break in our habits. More prosaically, many humanities professors are by temperament keen to spot the next big thing. But if we want to capture the nuances of historical continuity, we don't want every wrinkle to be a sea change" $(2006,9)$. Bordwell and Thompson have the impression that most contemporary puzzle films like Christopher Nolan's 2010 "Inception might be complicated rather than complex" $(2013,53)$, and find contemporary complex films to be essentially "part of business as usual” (Bordwell 2006, 73). 
ac.uk/scope/documents/2010/october-2010/andrews.pdf. Last accessed 26. 02. 2019.

Bailey, Jason. 2015. The 10 Best 'Mulholland Dr.' Fan Theories. Flavorwire, October 27. http://flavorwire.com/544908/the-10-best-mulholland-dr-fantheories. Last accessed 26. 02. 2019.

Baroni, Raphaël. 2011. Tellability. The Living Handbook of Narratology, https:// www.lhn.uni-hamburg.de/node/30.html. Last accessed 26. 02. 2019.

Bartyzel, Monika. 2010. Cinematic Movie Club: Mulholland Drive. Moviefone August 27. http://www.moviefone.com/2010/08/27/cinematical-movie-clubmulholland-drive/. Last accessed 19. 03. 2017.

Bordwell, David. 1979. The Art Cinema as a Mode of Film Practice. Film Criticism vol. 4: 56-64.

Bordwell, David. 1985. Narration in the Fiction Film. Madison, WI: University of Wisconsin Press.

Bordwell, David. 2002. Film Futures. SubStance vol. 31: 88-104.

Bordwell, David. 2006. The Way Hollywood Tells It. Berkeley and Los Angeles, CA: University of California Press.

Bordwell, David. 2017. Reinventing Hollywood: How 1940s Filmmakers Changed Movie Storytelling. Chicago: University of Chicago Press.

Bordwell, David and Kristin Thompson. 2013. Christopher Nolan. A Labyrinth of Linkages. Madison, WI: Irvington Way Institute Press.

Buckland, Warren. 2003. 'A Sad, Bad Traffic Accident': The Televisual Prehistory of David Lynch's Film Mulholland Dr. New Review of Film and Television Studies vol. 1, no. 1: 131-147.

Buckland, Warren, ed. 2009. Puzzle Films: Complex Storytelling in Contemporary Cinema. Oxford: Wiley-Blackwell.

Buckland, Warren, ed. 2014. Hollywood Puzzle Films. London: Routledge.

Branigan, Edward. 1992. Narrative Comprehension and Film. London and New York: Routledge.

Bruner, Jerome Seymour. 1991. The Narrative Construction of Reality. Critical Inquiry vol. 18: 1-21.

Cameron, Allan. 2008. Modular Narratives in Contemporary Cinema. Basingstoke: Palgrave Macmillan.

Campora, Matthew. 2014. Subjective Realist Cinema: From Expressionism to Inception. New York and Oxford: Berghahn.

Caracciolo, Marco. 2012. Narrative, Meaning, Interpretation: an Enactivist Approach. Phenomenology and the Cognitive Sciences vol. 11, no. 3: 367-384. 
Caracciolo, Marco. 2014. The Experientiality of Narrative. Berlin and Boston: De Gruyter.

Chandler, Daniel. 1997. An Introduction to Genre Theory. http://visual-memory. co.uk/daniel/Documents/intgenre/chandler_genre_theory.pdf. Last accessed 26. 02. 2019.

Culler, Jonathan. 1975. Structuralist Poetics. Structuralism, Linguistics and the Study of Literature. London: Routledge and Kegan Paul.

Ebert, Roger. 2001. Mulholland Drive. RogerEbert.com. http://www.rogerebert. com/reviews/mulholland-drive-2001. Last accessed 26. 02. 2019.

Ebert, Roger. 2002. Lost on 'Mulholland Drive.' RoberEbert.com. http://www. rogerebert.com/rogers-journal/lost-on-mulholland-drive. Last accessed 26. 02. 2019.

Eco, Umberto. 1994 [1990]. The Limits of Interpretation. Bloomington, IN: Indiana University Press.

Eig, Jonathan. 2003. A Beautiful Mind(Fuck): Hollywood Structures of Identity. Jump Cut vol. 46. www.ejumpcut.org/archive/jc46.2003/eig.mindfilms/index. html. Last accessed 26. 02. 2019.

Elsaesser, Thomas. 2009. The Mind-Game Film. In Puzzle Films: Complex Storytelling in Contemporary Cinema, ed. Warren Buckland, 13-41. Oxford: Wiley-Blackwell.

Elsaesser, Thomas. 2017. Contingency, Causality, Complexity: Distributed Agency in the Mind-game Film. New Review of Film and Television Studies vol. 16, no. 1: 1-39.

Fludernik, Monika. 1996. Towards a 'Natural' Narratology. London and New York: Routledge.

Grodal, Torben. 2009. Embodied Visions. Evolution, Emotion, Culture, and Film. New York: Oxford University Press.

Herman, David. 1997. Scripts, Sequences, and Stories: Elements of a Postclassical Narratology. PMLA vol. 5, no. 112: 1046-1059.

Hudson, Jennifer A. 2004. 'No Hay Banda, and yet We Hear a Band': David Lynch's Reversal of Coherence in Mulholland Drive. Journal of Film and Video vol. 56, no. 1: 17-24.

Jahn, Manfred. 1997. Frames, Preferences, and the Reading of Third-Person Narratives: Towards a Cognitive Narratology. Poetics Today vol. 18: 441-468.

Kauffmann, Stanley. 2001. Sense and Sensibility. New Republic, October 29. https://newrepublic.com/article/92197/david-lynch-mulholland-drive. Last accessed 26. 02. 2019. 
Kawin, Bruce F. 1978. Mindscreen: Bergman, Godard, and First-Person Film. Princeton: Princeton University Press.

Kiss, Miklós. 2012. Narrative Metalepsis as Diegetic Concept in Christopher Nolan's Inception. Acta Universitatis Sapientiae, Film and Media Studies vol. 5: 35-54.

Kiss, Miklós and Steven Willemsen. 2017. Impossible Puzzle Films: A Cognitive Approach to Contemporary Complex Cinema. Edinburgh: Edinburgh University Press.

Klecker, Cornelia. 2011. Chronology, Causality ... Confusion: When Avant-Garde Goes Classic. Journal of Film and Video vol. 63: 11-27.

Korthals Altes, Liesbeth. 2014. Ethos and Narrative Interpretation: The Negotiation of Values in Fiction. Lincoln, NE: University of Nebraska Press.

Kovács, András Bálint. 2007. Screening Modernism. European Art Cinema, 1950-1980. Chicago: University of Chicago Press.

Lewis, Robyn. 2002. Nice Film - If You Can Get It. The Guardian, January 17. https://www.theguardian.com/culture/2002/jan/17/artsfeatures.davidlynch. Last accessed 26. 02. 2019.

Lim, Dennis. 2015. The Man from Another Place. Boston, New York: New Harvest. McGowan, Todd. 2004. Lost on Mulholland Drive: Navigating David Lynch's Panegyric to Hollywood Author(s). Cinema Journal vol. 43: 67-89.

Minsky, Marvin. 1974. A Framework for Representing Knowledge. Artificial Intelligence Memo no. 306.

Mittell, Jason. 2009. Lost in a Great Story: Evaluation in Narrative Television (and Television Studies). In Reading Lost, ed. Roberta Pearson, 119-128. London and New York: I. B. Tauris.

Mittell, Jason. 2013. Haunted by Seriality: The Formal Uncanny of Mulholland Drive. Cinephile vol. 9: 26-32.

Neale, Steve. 1981. Art Cinema as Institution. Screen vol. 22: 11-40.

Nieland, Justus. 2012. David Lynch. Urbana, Chicago and Springfield: University of Illinois Press.

Nochimson, Martha P. 2002. Mulholland Drive. Film Quarterly vol. 56, no. 1: $37-45$.

Norelli, Clare Nina. 2009. Suburban Dread: The Music of Angelo Badalamenti in the Films of David Lynch. Sound Scripts vol. 2: 38-43.

Olson, Greg. 2008. David Lynch: Beautiful Dark. Lanham: The Scarecrow Press.

Perlmutter, Ruth. 2005. Memories, Dreams, Screens. Quarterly Review of Film and Video vol. 22, no. 2: 125-134. 
Panek, Elliot. 2006. The Poet and the Detective: Defining the Psychological Puzzle Film. Film Criticism vol. 31: 62-88.

Scott, A. O. 2001. Critic's Notebook; Shoving Through the Crowd to Taste Lyrical Nostalgia. The New York Times, May 17. http://www.nytimes.com/2001/05/17/ movies/critic-s-notebook-shoving-through-the-crowd-to-taste-lyricalnostalgia.html. Last accessed 26. 02. 2019.

Thanouli, Eleftheria. 2006. Post-Classical Narration: A New Paradigm in Contemporary Cinema. New Review of Film and Television Studies vol. 4, no. 3: 183-196.

Thanouli, Eleftheria. 2009. Art Cinema Narration: Breaking Down a Wayward Paradigm. Scope vol. 14: 1-14. https://www.nottingham.ac.uk/scope/ documents/2009/june-2009/thanouli.pdf. Last accessed 26. 02. 2019.

Todorov, Tzvetan. 1975 [1973]. The Fantastic: A Structural Approach to a Literary Genre. Ithaca: Cornell University Press.

Toles, George. 2004. Auditioning Betty in Mulholland Drive. Film Quarterly vol. 58: 2-13.

Vishnevetsky, Ignatiy. 2015. Mulholland Dr. Defined the Modern Puzzle-Box Movie. AV Club, October 28. http://www.avclub.com/review/mulholland-drdefined-modern-puzzle-box-movie-227497. Last accessed 26. 02. 2019.

Wallace, David Foster. 1998. A Supposedly Fun Thing I'll Never Do Again: Essays and Arguments. London: Abacus.

Winter, Max. 2015. Poetic Logic: On David Lynch’s 'Mulholland Dr.' RogerEbert. com. http://www.rogerebert.com/balder-and-dash/poetic-logic-on-davidlynchs-mulholland-dr. Last accessed 26. 02. 2019. 